DOI: https://doi.org/10.32839/2304-5809/2021-11-99-60

УДК 159.91

Мишко Н.М.

Полтавський національний педагогічний університет імені В.Г. Короленка

\title{
ПРОЯВ БУЛІНГУ У СЕРЕДОВИЩІ МОЛОДШИХ ПІДЛІТКІВ
}

\begin{abstract}
Анотація. Висвітлено питання проявів булінгу в молодшому підлітковому віці. Проаналізовано основні психологічні характеристики даного віку, що можуть бути основою для прояву підліткового цькування. Це і зростання важливості міжособистісних стосунків в цьому віці, і відчуття нерівності у цій взаємодії за різними критеріями. Розкрито основні прояви булінгу в цьому віці такі, як глузування, налаштування одних дітей проти інших, ізолящія, вимагання грошей та ін. Аналізуючи дослідження критеріїв булінгу, можна говорити про те, що шкали небезпеки і роз'єднаності вказують на високу вираженість ризику булінгу, оскільки характеризують високий рівень агресивності, тривожності та соціальної ізоляції, що служить передумовою до появи систематичних аутсайдерів, жертв цькування і вибудовування іерархічних, владних відносин, де у всіх учасників високий рівень тривоги щодо свого статусу в учнівському колективі. Показник за шкалою благополуччя може свідчити також про те, що молодші підлітки відзначають наявність факторів, які сприяють клімату довіри, утвердження поваги як норми в групі і відкритого діалогу в школі.
\end{abstract}

Ключові слова: булінг (цькування), молодший підліток, асертивна поведінка.

Myshko Nadiia

Poltava V.G. Korolenko National Pedagogical University

\section{MANIFESTATION OF BULLYING AMONG YOUNG TEENAGERS}

Summary. The article covers the issue of bullying in early adolescence. It analyzes the main psychological characteristics of teenagers, which may be the basis for the manifestation of bullying. It is about the growing importance of interpersonal relationships at this age, and the feeling of inequality in this interaction by different criteria. The main manifestations of bullying at this age are revealed, such as ridicule, setting some children against others, isolation, extortion, etc. The results of our own research are analyzed. According to these results, the predominance of low values of independence of younger teenagers was revealed. This indicates a certain lack of independence, and uncertainty and the need for an authoritative figure who will resolve complex issues. A study of the self-confidence of younger teenagers revealed the presence of assertiveness, but only in typical situations. Analyzing the criteria for bullying, we can say that the scales of danger and disunity indicate a high risk of bullying, as they characterize a high level of aggression, anxiety and social isolation, which is a prerequisite for the emergence of systematic outsiders, victims of harassment and hierarchical power. Where all participants have a high level of anxiety about their status in the student body. Part of the scales of the method characterizes the risk of bullying, part on the contrary, indicates psychological safety. Indicators of well-being by this method may also indicate that younger teenagers note the presence of factors that contribute to a climate of trust, the establishment of respect as the norm in the group and open dialogue at school. Considering the obtained general data, we note that the boys in the study group of younger teenagers have a higher score on the scale of danger and disunity than the girls in the same sample. And, given the fact that these two scales reflect the high severity of bullying expectations, we can say that boys have a slightly higher rate of bullying expectations than girls. Also, boys, compared to girls, are more prone to loneliness and distance, lack of close contact in the team and the tension in this regard. And girls, unlike boys, feel more support and acceptance from others, which allows them to perceive the environment of their learning and communication as safer for themselves.

Keywords: bullying, young teenager, assertive behavior.

Постановка проблеми. Соціально-еконо-

1 мічні та політичні процеси, що відбуваються в останні десятиліття в Україні призвели до переосмислення значущості багатьох як індивідуальних, так і суспільних цінностей, зміни соціальних стереотипів та міжособистісної взаємодії. Зважаючи на це, готовність та вміння відстоювати власну позицію й діяти незалежно від думки більшості можуть бути доленосними, як для окремої людини, так і суспільства загалом. Отже, проблема булінгу (цькування) в сучасному суспільстві стає особливо актуальною як у сощіальному, так і в науковому аспектах.

Аналіз останніх досліджень і публікацій. Центральне місце в розвитку теорії буллінгу зайняла робота D. Olweus (1978). Розроблена цим автором модель буллінгу в освітньому середовищі послужила основою подальших досліджень цієї проблеми таких авторів як Hazler, 1985;
Besag, 1989; Roland, 1989; Slee, 1995; Arora, 1998; Kwak, 1999; Lane, 1999; Lee, 1999; Rigby, 2000; Heald, 2000; I.C. Кон, 2006; Кутузова Д.А., 2007; Маланцева O.А., 2007; Глазман О.К., 2009; Ачітаева І.Б., 2010; Стрельбицький А.А., 2010; Файнштейн Є.I., 2010; Петросянс В.P., 2011 та ін.

Виділення невирішених раніше частин загальної проблеми, яким присвячуеться стаття - поза увагою вчених залишаються питання дослідження булінгу саме в молодшому підлітковому віці.

Мета статті - визначити особливості розвитку психологічних особливостей асертивності молодших підлітків.

Виклад основного матеріалу дослідження. $\mathrm{У}$ вітчизняній психології підлітковий вік ділять на два етапи від 9 до 12-13 років (молодший підліток), і від 12-13 років до 17-18 років (старший підліток). У молодшому підлітковому 
віці для дітей стають важливішими стосунки 3 однолітками. Вони гуртуються за вподобаннями, з'являються перші закоханості та антипатії. Водночас діти розвиваються нерівномірно, тому зовнішні відмінності (зміни фрігури, зросту, ваги) викликають у дітей цікавість [2]. Якщо діти не отримують пояснень про відмінності та розвиток власного тіла, це може спровокувати глузування та булінг (цькування). В цей період триває статеве дозрівання, зміни настрою, гормональні зміни, які можуть впливати на поведінку дітей. Також діти звертають увагу на економічну нерівність у групі (різні фінансові можливості), якість одягу та особистих речей, якими користуються однолітки. Основними проявами булінгу у молодшому підлітковому віці є: фрізична кривда, шантаж, економічний булінг (вимагання коштів, крадіжка та псування речей тощо), бойкот, соціальна ізоляція, глузування, поширення пліток, налаштування інших дітей проти тощо. Найпоширенішою причиною булінгу в цьому віці є прагнення до подолання почуття неповноцінності, а в результаті такий підліток починає самостверджуватись через насильство [5].

Батьки підлітків разом із працівниками закладів освіти ставлять за мету всебічний розвиток дитини, створення умов для засвоєння ефективних моделей поведінки з ровесниками. Проте часті явища булінгу та високий рівень конфрліктності серед однолітків не дозволяе повною мірою досягти поставлених цілей [1].

Законом визначено, що булінг (цькування) це діяння учасників освітнього процесу, які полягають у психологічному, фрізичному, економічному, сексуальному насильстві, у тому числі iз застосуванням засобів електронних комунікацій, що вчиняються стосовно малолітньої чи неповнолітньої особи або такою особою стосовно інших учасників освітнього процесу, внаслідок чого могла бути чи була заподіяна шкода психічному або фізичному здоров'ю потерпілого [3]. На сьогоднішній день тема булінгу є досить резонансною. Новини шокують суспільство проявами підліткової жорстокості, виводячи це питання далеко вперед від багатьох інших. За даними досліджень, Україна увійшла до ТОП-10 країн із поширеною дитячою агресією у школах.

Таким чином, виникла ідея проаналізувати ситуацію з булінгом у молодших підлітків. Емпірична частина дослідження виконувалася на базі Полтавської гімназії в жовтні 2020 року. Дослідженням охоплено 60 молодших підлітків, 3 яких 34 дівчинки та 26 хлопщів віком 10-11 років. Учасникам було запропоновано анкети, що включали питання, які характеризують рівень розвитку показників асертивності досліджуваного та особливості сприйняття ризиків булінгу. Статистична обробка даних проводилася за допомогою t-критерію Стьюдента (IBM SPSS Statistics 20).

За результатами дослідження рівня асертивності (методика у модифікації В. Каппоні, Т. Новак), для даної вибірки характерним є переважання низьких та середніх значень усіх субшкал тесту. Переважання низьких значень (73\% досліджуваних, 3 яких $26 \%$ хлопців та $47 \%$ дівчат) по шкалі "Незалежності" говорить про залежність таких підлітків від оточуючих людей, несамо- стійність і невпевненість у собі. Такі підлітки не здатні вирішувати свої проблеми самостійно, і відповідати за себе і свої вчинки. 10\% молодших підлітків (10\% хлопців та 0\% дівчат) навпаки мають егоцентризм, схильність переоцінювати свої можливості. Такий підліток занадто незалежний i не прислухається до слів інших, а спроби поводитися асертивно часто виливаються в агресію. Лише $17 \%$ молодших підлітків (7\% хлопщів та 10\% дівчат) здатні проявляти незалежність, але у своїй незалежності все ж з увагою і повагою ставляться до думок інших людей. Такий підліток реалістично оцінюе свої можливості, самостійний, досягає бажаної мети, не завдаючи шкоди оточуючим. По шкалі "Упевненості у собі» більшість молодших підлітків (43\% досліджуваних, 3 яких 20\% хлопців та 23\% дівчат) мають низькі показники, що свідчать про їх сильний неконтрольований страх перед непередбачуваними ситуаціями. 40\% підлітків (17\% хлопців та $23 \%$ дівчат) характеризуються наявністю асертивності в типових для них ситуаціях, але найменша зміна обставин руйнуе у них почуття впевненості в собі. І лише 17\% молодших підлітків (7\% хлопців та 10\% дівчат) точно знають, чого хочуть, здатні іти до мети, спираючись на свої власні сили. При зіткненні інтересів такий підліток здатний домовитися і знайти компромісне рішення, яке задовольняе обидві сторони. Він домагається свого, не маніпулюючи опонентами за допомогою почуття провини чи будь-яким іншим способом із розряду прийомів емоційного шантажу. Така дитина впевнена в собі, діє чітко і рішуче. Таким чином, можна говорити про важливість втручання небайдужих дорослих (в першу чергу вчителів, а також батьків, старшокласників, інших шкільних співробітників тощо) для запобігання конфрліктних ситуацій та укорінення норм безпеки і взаємоповаги в середовищі молодших підлітків.

Порівнюючи між собою показники хлопців i дівчат, статистично значимі відмінності за t-критерієм Стьюдента було встановлено за показниками «Незалежності» ( $\mathrm{t}=11,21, \mathrm{p} \leq 0,05)$ та «Соціальної бажаності» $(\mathrm{t}=-3,94, \mathrm{p} \leq 0,05)$, що свідчить про те, що хлопцям важливіше в соціальному житті опиратися на власну точку зору, проявляти егоцентризм, досягаючи власної мети. А дівчатам важливіше спрямовувати свою енергію на створення сприятливої думки про себе в очах оточуючих.

Наступним кроком ми проаналізували особливості сприйняття молодшими підлітками ризиків булінгу дослідження по методищі А.А. Бочавера, В.Б. Кузнецової, Е.М. Біанкі, П.В. Дмитрієвського. За результатами дослідження, переважаючим $є$ показники по шкалі "Небезпеки". Високі показники за цією шкалою говорять про посилення суб'єктивного відчуття небезпеки у учасників групи. Тобто, 37\% досліджуваної групи молодших підлітків (39\% хлопців і $35 \%$ дівчат), відчувають негативні аспекти психологічної атмосфери, фонової напруги в класі, яка пов'язана 3 низькою якістю взаємовідношень і недотриманням правил і кордонів у спілкування, що призводить до негативних установок в спілкуванні: роздратування, негативізму і підозрілості відносно перспектив і якості комунікації. 
Натомість, маемо показник $30 \%$ за шкалою "Благополуччя" (23\% хлопщів і 29\% дівчат). Це може свідчити про те, що молодші підлітки відзначають фактори, які сприяють клімату довіри, утвердження поваги як норми в групі і відкритого діалогу в школі. Вони оцінюють стійкість кордонів і правил комунікацій в середовищі, що забезпечуе зниження рівня негативних установок по відношенню до взаємодії і спілкування. Що служить фактором захисту від ризику розвитку ситуацій булінгу i, як наслідок, знижуе сприйняття ймовірності цькування.

Показник "Сприйняття роз'єднаності в досліджуваній групі молодших підлітків становить $13 \%$ (39\% хлопців і $35 \%$ дівчат). Ці показники свідчать про відсутність згуртованості, наявність дистанції між підлітками, а також між ними і вчителями через відсутність традицій підтримки і можливості діалогу. Такі підлітки мають безпосередні ситуативні причини напруги, що викликаються, наприклад, бійками та періодичними суперечками. Це може призводити до негативних, агресивних установок по відношенню до спілкування, і одночасно до високого ступеню тривоги в поєднанні 3 переживанням самотності. Це не обумовлюе булінг безпосередньо, проте при розвитку ситуації цькування знижуе ймовірність його припинення, оскільки в групі відсутні взаємовиручка і підтримка.

Частина шкал методики характеризуе ризик булінгу, частина навпаки, свідчить про психологічну безпеку. За шкалою "Рівноправності» має мо показник $20 \%$ (15\% хлопців і $24 \%$ дівчат). Тобто, можемо говорити про те, що в групі присутні прояви агресивності, проте вони мають таку форму, що не лякають членів групи і не сприяють їх ізоляції один від одного, а, навпаки, поєднуються 3 поважними і приймаючими різноманітність відносинами. Дані вказують на те, що п’ята частина досліджуваної вибірки відчуває, що в групі розподілені ролі, е діалогічність відносини, що, в свою чергу, знижуе тривогу і захищае їх від ризику розгортання цькування на тлі вибудовування системи соціальних статусів.

Аналізуючи критерії булінгу, можна говорити про те, що шкали небезпеки і роз'єднаності вказують на високу вираженість ризику булінгу, оскільки характеризують високий рівень агресивності, тривожності та соціальної ізоляції, що служить передумовою до появи систематичних аутсайдерів, жертв џькування і вибудовування ієрархічних, владних відносин, де у всіх учасників високий рівень тривоги щодо свого статусу в учнівському колективі.

Розглядаючи отримані загальні дані відзначимо, що хлопці досліджуваної групи молодших підлітків мають більш високі показники за шкалою небезпеки і роз'єднаності, ніж дівчата ціеі ж вибірки. А, враховуючи той фракт, що саме ці дві шкали відображають високу вираженість очікування булінгу, можемо говорити про те, що хлопці мають дещо вищий показник очікування булінгу, ніж дівчата.

Порівнюючи між собою показники особливостей сприйняття молодшими підлітками ризиків булінгу у хлопців і дівчат, статистично значимі відмінності за t-критерієм
Стьюдента було встановлено за показниками «Роз'єднаності» $(\mathrm{t}=5,03, \mathrm{p} \leq 0,05)$ та «Рівноправності» $(\mathrm{t}=-3,22, \mathrm{p} \leq 0,05)$. Що говорить про те, що хлопщі, у порівнянні з дівчатами, більше схильні до сприйняття самотності та дистанції, відсутності близьких контактів в колективі і напруги у зв'язку 3 цим. А дівчата, на відміну від хлопців, більше відчувають підтримку і прийняття 3 боку оточуючих, що дозволяе їм сприймати середовище свого навчання і спілкування як більш безпечне для себе.

Висновки і перспективи подальшого розвитку. Таким чином, основною загрозою гармонійного розвитку особистості в підлітковому середовищі $е$ булінг або цькування у різних його видах і проявах. Це явище стосуеться і впливає на всіх його учасників, негативно позначається на психічному розвиткові дітей, створюе загрозу здоров'ю та життю підлітка, призводячи до порушення навчально-виховного процесу в школі, викликае важкі наслідки для особистості, інколи віддалені в часі. Тому постає гостра потреба усвідомлення сутності ціеї проблеми та можливих шляхів його попередження починаючи з віку молодшого підлітка, коли це явище вперше постає перед особистістю.

Вирішення означених проблем актуалізуе питання побудови безпечного, мирного освітнього простору, який передбачае впровадження в систему освіти технології вирішення конфліктів шляхом співробітництва. Важливими кроками в цьому напрямі е формування у здобувачів освіти здатності протистояти булінгу, навичок ненасильницької поведінки, побудови конструктивного діалогу, асертивності у взаєминах з оточуючими.

Важливо постійно нагадувати дітям, що булінг - це погана звичка, як "хвороба» групи. Це вчинки, до яких всі звикають, але які неприемні для групи і заважають навчатись разом. Кожна людина мае почуття і право на повагу. Ніхто не хоче бути ображеним, тому важливо дотримуватися правил, рівних для кожного.

Учні цього віку схильні слідкувати за модою, намагаються бути крутими у власному розумінні. Формування правильних цінностей, які стоять за ролями «крутий», «популярний», «модний» - це той місток, який може поєднати розуміння дітей i наші прагнення врегулювати ситуацію. Важливо прояснити, чи дійсно це «круто» кривдити інших? Як самі діти до цього ставляться? Треба вчити дітей говорити про те, що їм не подобаеться. Для цього необхідно досягти спільних домовленостей щодо того, як діти будуть говорити одне з одним, коли їм щось не подобаеться; до кого із дорослих вони будуть звертатись, якщо на їхні прохання припинити не реагують; яким чином будуть вирішуватися ці ситуації: бесіди з учасниками, залучення батьків, психолога, інших служб тощо.

Важливо до побудови спільних правил життя в учнівському соціумі долучати самих дітей. Заохочувати їх дотримуватися та нести спільну відповідальність за їх невиконання. Головним повинно стати не кількість заходів, проведених з молодшими підлітками, а покращення безпосередньо рівня психологічного комфорту в закладі освіти, який відмічають самі діти. 


\section{Список літератури:}

1. Андреенкова В.Л., Левченко К.Б., Лунченко Н.В., Матвійчук М.М. Комплект освітніх програм «Вирішення конфліктів мирним шляхом. Базові навички медіації». Київ, 2018. 140 с.

2. Скрипченко О.В., Долинська Л.В., Огороднійчук З.В. та ін. Вікова та педагогічна психологія : навч. посіб. Київ : Просвіта, 2001. 416 с.

3. Закон України «Про внесення змін до деяких законодавчих актів щодо протидії булінгу». URL: https://zakon.rada.gov.ua/laws/show/2657-19\#Text

4. Langan P. Bullying in Schools: What You Need to Know. URL: http://kazkarka.com/books/posibnyk-pro-bulinh.htm

5. Olweus D. Bullying at school: Long-term outcomes for the victims and aneffective school-based intervention program. Aggressivebehavior: Currentperspectives. NewYork : PlenumPress, 1994. P. 97-130.

\section{References:}

1. Andrieienkova V.L., Levchenko K.B., Lunchenko N.V., Matviichuk M.M. (2018) A set of educational programs «Conflict resolution peacefully. Basic mediation skills». Kyiv, 140 p.

2. Skrypchenko O.V., Dolynska L.V., Ohorodniichuk Z.V. and others (2001) Age and pedagogical psychology: textbook. Kyiv: Prosvita, 416 p.

3. Law of Ukraine "On Amendments to Certain Legislative Acts on Combating Bullying". Available at: https://zakon.rada.gov.ua/laws/show/2657-19\#Text

4. Langan P. (1993) Bullying in Schools: What You Need to Know. Available at: http://kazkarka.com/books/posibnykpro-bulinh.htm

5. Olweus D. (1994) Bullying at school: Long-term outcomes for the victims and aneffective school-based intervention program. Aggressivebehavior: Currentperspectives. NewYork: PlenumPress, pp. 97-130. 